the graphite. Besides satisfying all the lubricating needs of the cylinder, the joints, where gum is used, last longer, and show less of leakage. At 30 cents per pound, this engine would require $1 \frac{1}{6}$ cents' worth per day.

J. H. C.

\title{
Improved Method of Managing Steam-Boiler Fires.-
} When the furnace-door of a steam boiler is opened, there should be a simultaneous partial closing of the damper to prevent sudden chilling of the boiler and flues. To accomplish this, with certainty, for every opening of the doors, Mr. Wm. Weightman, of Powers \& Weightman, has had arranged and applied a system of levers and rods, connecting the furnace-door with the damper, so contrived that whether there be one or more doors to one furnace, or to which one damper is supplied, the act of opening any one door will invariably close the damper. Whether this application of simple and ingenious devices is new, or not, every engineer will regard it as one of the good things for aiding the better management of steam-boilers.

J. H. C.

New Leveling Device.-Every millwright experiences difficulty in leveling shafting, when pulleys, hangers, walls, etc., are in the way of applying the "straight edge" from bearing to bearing which it is desired to bring to a level. Mr. Geo. Jennison, millwright at Powers and Weightman's, has adapted a very simple and readily applied apparatus, which can be used without the usual "level boards" and "straight edges," and without regard to the obstructions in the way.

He takes an ordinary $\frac{3}{8}$ " or $\frac{1}{2}$ " gum tube, say 16 or 20 feet long, and to each end secures a stout glass tube $10^{\prime \prime}$ to $12^{\prime \prime}$ long; fills the gum tube with water to within, say, $4^{\prime \prime}$ of each end of the glass tubes, puts a cork in each, and the apparatus is complete. To use this, hold each glass vertically at the bearings, and withdraw the corks; the water will soon find its level, and show how the bearings stand with regard to the level line.

J. H. C.

The Liquefaction of Gases, and the Artificial Production of Low Temperatures.-In the JourNaL of THE FrankLIN Institute for January, 1874 (p. 9), will be found a brief notice, by Prof. E. J. Houston, of a German refrigerating machine, proposed for making ice. Prof. Houston, after commenting upon the method of employment of the cold of expansion as the agent for the removal 